\title{
Kinetics of the secretion of Bacillus subtilis levanase overproduced during the exponential phase of growth
}

\author{
Laurence Leloup, Jérome Le Saux, Marie-Françoise Petit-Glatron \\ and Régis Chambert
}

\author{
Author for correspondence: Régis Chambert. Tel: +331442749 17. Fax: +33144275994. \\ e-mail: chambert@ccr.jussieu.fr
}

Institut Jacques Monod CNRS, Universités Paris 6 et Paris 7, Laboratoire Génétique et Membranes, Tour 43-2, place Jussieu, F-75251 Paris Cedex 05, France

\begin{abstract}
The Bacillus subtilis levanase structural gene sacC was expressed under the regulated control of sacR, the inducible levansucrase leader region, in a degU32(Hy) strain. In this genetic context, exocellular levanase is overproduced $(0.5 \%$ of total protein) during the exponential phase of growth upon induction by sucrose at $37^{\circ} \mathrm{C}$ and pH 7. No precursor form that comprised a signal peptide was detected in pulse-chase experiments. The subsequent release of the cell-associated processed protein is a slow event $\left(t_{1 / 2}=80 \pm 10 \mathrm{~s}\right)$. The unfolding-folding transition of pure levanase monitored in vitro by the resistance to proteolysis was achieved within the same time range $\left(t_{1 / 2}=50 \mathrm{~s}\right)$ under the same conditions of $\mathrm{pH}$ and temperature. Calcium ions, which modulate the rate and the yield of refolding, have a low affinity for the protein. Comparison of these results with those obtained previously with levansucrase and $\alpha$-amylase overproduced in the same genetic and physiological context suggests that the precursor processing is more efficient in levanase and $\alpha$-amylase than in levansucrase. This discrepancy could lie in information borne by the signal peptide sequence of these exoproteins. However, the rate of the ultimate stage of release of these three proteins, which includes the passage through the cell wall, is correlated with the rate of folding and appears to be independent of their molecular size.
\end{abstract}

Keywords: levanase, protein secretion, late stage of secretion, folding, Bacillus subtilis

\section{INTRODUCTION}

We have recently shown (Leloup et al., 1997) that the expression of the structural gene amyE under the control of the inducible levansucrase leader region $s a c R$ in a $\operatorname{degU} 32(\mathrm{Hy})$ strain leads to an overproduction of $\alpha$ amylase. Such a context was suitable for the characterization in vivo of the sequential events of the secretion process of $\alpha$-amylase.

Comparison of the levansucrase and $\alpha$-amylase secretion mechanisms drew our attention to the fact that cleavage of the $\alpha$-amylase signal peptide was more rapid than that of levansucrase (Petit-Glatron et al., 1987; Leloup et al., 1997). Nevertheless, for both proteins, the final stage of mature protein release is slow, $t_{1 / 2}=60 \mathrm{~s}$ and $120 \mathrm{~s}$ for levansucrase and $\alpha$-amylase, respectively, and is seemingly coupled with the folding.

The efficiency of the membrane translocation process could therefore be specific to each exoprotein family, such as proteins produced and secreted during the exponential phase (levansucrase) or the stationary phase (levanase or $\alpha$-amylase), whereas the mechanism underlying the final release could be common. In the present work, we examined the levanase $\mathrm{SacC}$ secretion pathway to test the validity of this general outline. We chose this protein for the following reasons. (i) Its signal sequence region (Schörgendorfer et al., 1987) displays, like $\alpha$ amylase, a hydrophobicity twice that of levansucrase (Scotti et al., 1996). Is this feature therefore correlated with the efficiency of the translocation mechanism? (ii) This protein has a higher molecular mass, $73 \mathrm{kDa}$, than levansucrase $(50 \mathrm{kDa})$. Does such a difference affect the rate of release, which includes the passage through the cell wall, or does this rate only correlate with the folding kinetics of the protein? The answers to these questions could provide new information about each stage of the general mechanism of secretion we propose (PetitGlatron et al., 1987; Leloup et al., 1997).

Bacillus subtilis levanase is secreted at a low level during 
the stationary phase of growth in the wild-type strain 168 Marburg (Fuchs, 1959), and degU32(Hy) mutations inducing overproduction of several exocellular enzymes do not cause overproduction of levanase (Kunst et al., 1977).

Characterization in vivo of the sequential events that lead up to secretion of levanase is not possible by conventional biochemical methods in this context of low production. We therefore placed $s a c C$ under the regulated control of $s a c R$, the levansucrase leader region, in a $\operatorname{deg} U 32(\mathrm{Hy})$ strain. Under these conditions levanase is overproduced and it is then possible to compare its secretion with that of $\alpha$-amylase and levansucrase in the same genetic context and under the same growth conditions.

\section{METHODS}

Strains and media. The Bacillus subtilis strain GM96201 contained a $s a c R-s a c C$ fusion which was introduced into the chromosome of strain GM96100, as previously described (Leloup et al., 1997). Bacteria were grown at $37^{\circ} \mathrm{C}$ in minimal medium (Chambert \& Petit-Glatron, 1984) supplemented with $1 \%(\mathrm{w} / \mathrm{v})$ glucose and $0.5 \mathrm{mM} \mathrm{CaCl} \mathrm{Ca}_{2}$. Strains and plasmids are listed in Table 1.

Plasmid and DNA manipulation. The DNA fragments carrying $s a c C$, the levanase structural gene including its signal sequence, or $s a c R$, the $s a c B$ (levansucrase structural gene) leader region, were amplified by PCR (Petit-Glatron \& Chambert, 1992) with the chromosomal DNA of strain QB112 or pLS50 (Steinmetz et al., 1985) as templates and A and B or C and D oligonucleotides for $s a c C$ and $s a c R$, respectively: $A, 5$ AAGGAGACGTCAACGATG 3' (forward primer), and B, 5' AAAGGCCTGCAGAACACCTGATGATTTGG 3' (reverse primer), with AatII and StuI sites (shown in bold) in A and B, respectively; C, 5' CGCGGATCCTTTTTAACCCATCAC-
ATATACCTG 3' (forward primer), and D, 5' CATCGTTGACGTCTCCTT 3' (reverse primer), with BamHI and AatII sites (in bold) at the $5^{\prime}$ end of $\mathrm{C}$ and $\mathrm{D}$, respectively.

The restriction sites were included in the primers to facilitate subsequent in-frame fusion of the regulatory region and the coding sequence, and insertion into the appropriate vector. The amplified fragments were purified by electroelution after electrophoresis on an agarose gel. The fragments were then blunted by $P f u$ DNA polymerase treatment and inserted into the $S r f l$ site of the $\mathrm{pCR}(+)$ vector according to the supplier's recommendations (Stratagene), resulting in plasmids pGMC9 and pGMC10. The BamHI-AatII fragment (sacR) of pGMC9 was purified and ligated into pGMC10 (containing the $\mathrm{sacC}$ fragment) digested with the same endonucleases. The resulting plasmid was used to transform Escherichia coli TG1. In these plasmids, which were purified from E. coli transformants and exhibited fragments of the expected size after digestion by various endonucleases, we verified the in-frame fusion between the two DNA fragments by sequencing the amplified fragments, using the Sequenase kit (USB) and double-stranded plasmid DNA. The presence of active levanase was assayed in the cell extracts of $E$. coli transformants. One appropriate plasmid, pGMC11, was selected and used for construction of strain GM96201.

Enzyme assay. Activity of levanase was assayed in the presence of uniformly labelled $\left[{ }^{14} \mathrm{C}\right]$ levan in $0 \cdot 1 \mathrm{M}$ sodium phosphate, $\mathrm{pH} 6$, at $37^{\circ} \mathrm{C} .\left[{ }^{14} \mathrm{C}\right]$ Fructose released from the levan hydrolysis was quantitatively analysed by TLC on silica gel TLC foils (Schleicher \& Schuell) developed in butan-1-ol/propan2 -ol/water $\left(3: 12: 4\right.$, by vol). Uniformly labelled $\left[{ }^{14} \mathrm{C}\right]$ levan was obtained from the action of immobilized levansucrase on $\left[{ }^{14} \mathrm{C}\right]$ sucrose (Chambert \& Petit-Glatron, 1993). One unit of enzyme activity was defined as the amount of enzyme that releases one $\mu \mathrm{mol}$ fructose $\mathrm{min}^{-1}$ in the presence of $10 \mathrm{mg}$ labelled levan $\mathrm{ml}^{-1}$ (which corresponds to $0.06 \mathrm{M}$ fructosyl unit). One enzyme unit corresponds to $8.5 \mu \mathrm{g}$ pure levanase.

Gel electrophoresis and immunoblotting. Proteins were analysed by $10 \%(\mathrm{w} / \mathrm{v})$ SDS-PAGE and the cell-associated

Table 1. Strains and plasmids

\begin{tabular}{|c|c|c|}
\hline Strain/plasmid & Relevant genotype and phenotype & Source/reference \\
\hline \multicolumn{3}{|l|}{ Strains } \\
\hline QB112 & $\operatorname{deg} U 32(\mathrm{Hy}) \operatorname{sac} A 321$ & Lepesant et al. (1976) \\
\hline GM96100 & $\operatorname{deg} U 32(\mathrm{Hy}) \operatorname{sacA} 321 \Delta s a c R-s a c B\left(\mathrm{Sp}^{\mathrm{R}}\right)$ & Leloup et al. (1997) \\
\hline GM96201 & $\begin{array}{l}\operatorname{deg} U 32(\mathrm{Hy}) \operatorname{sacA} 321 \Delta s a c R-s a c B \\
\operatorname{sacR-sacC}\left(\mathrm{Km}^{\mathrm{R}} \mathrm{Sp}^{\mathrm{R}} \mathrm{Cm}^{\mathrm{R}}\right)^{*}\end{array}$ & This work \\
\hline \multicolumn{3}{|l|}{ Plasmids } \\
\hline pLS50 & $\begin{array}{l}\text { B. subtilis sacR-sacB region inserted into } \\
\text { pJH101† }\left(\mathrm{Cm}^{\mathrm{R}}\right)\end{array}$ & Steinmetz et al. (1985) \\
\hline pGMK50 & pLS50 $\left(\mathrm{Km}^{\mathrm{R}}\right)$ & Petit-Glatron \& Chambert (1992) \\
\hline pGMK64 & $\begin{array}{l}\text { pGMK50 deleted of the BamHI-EcoRV } \\
\text { fragment and with the } s a c R-s a c C \text { fusion } \\
(\text { Bam } \mathrm{HI}-\text { StuI }) \text { ligated at these sites }\end{array}$ & 'This work \\
\hline pGMC9 & $\mathrm{pCR}(+)[\mathrm{pBluescript}$ II SK$(+)] \operatorname{sacR}$ & This work \\
\hline pGMC10 & $\mathrm{pCR}(+)[\mathrm{pBluescript}$ II SK$(+)]$ sacC & This work \\
\hline pGMC11 & $\mathrm{pCR}(+) s a c R-s a c C$ & This work \\
\hline
\end{tabular}

* This construct was created by Campbell-like integration.

t $\mathrm{pJH} 101$ derived from plasmid pBR322 by insertion of the $1 \mathrm{~kb}$ cat gene from pC194 into the PvuII site (Ferrari et al., 1983). 
forms of levanase were analysed by immunoblotting as described previously (Petit-Glatron et al., 1987).

Pulse-chase experiment. Under the usual conditions of growth, B. subtilis cells were induced with sucrose $(60 \mathrm{mM}$ final concentration) and pulse-labelled at an $\mathrm{OD}_{600}$ of 2 by adding $\left.0.25 \mathrm{mCi}(9 \mathrm{MBq}){ }^{3{ }^{35}} \mathrm{~S}\right]$ methionine $\left(800 \mathrm{Ci} \mathrm{mmol}^{-1}\right)$ to $1 \mathrm{ml}$ culture suspension maintained at $37^{\circ} \mathrm{C}$. After a pulse period of $30 \mathrm{~s}$, non-radioactive methionine $(4 \mathrm{mM}$ final concentration) was added. Samples of $0.2 \mathrm{ml}$ were withdrawn at intervals and all reactions were immediately stopped by diluting the samples threefold with ice-cold stopping buffer $(0 \cdot 1 \mathrm{M}$ sodium phosphate, $\mathrm{pH} 7$, containing $2 \cdot 4 \mathrm{M} \mathrm{KCl}, 200 \mu \mathrm{g}$ chloramphenicol ml ${ }^{-1}$ and $0 \cdot 2 \mathrm{mM}$ PMSF). Cell suspensions were centrifuged and the supernatants were dialysed overnight at $4{ }^{\circ} \mathrm{C}$ against TNE buffer $(50 \mathrm{mM}$ Tris/ $\mathrm{HCl}, \mathrm{pH} 8$, containing $150 \mathrm{mM} \mathrm{NaCl}$ and $5 \mathrm{mM} \mathrm{EDTA}$ ) and diluted fivefold in TNET (TNE buffer containing 1\%, v/v, Triton X-100). The bacterial pellets were washed with ice-cold stopping buffer without $\mathrm{KCl}$, resuspended in $0.3 \mathrm{ml}$ TNES (TNE buffer containing $2 \%, \mathrm{w} / \mathrm{v}, \mathrm{SDS}$ ) and diluted fivefold in TNET. Cells were disrupted by sonication. The suspensions were incubated for $5 \mathrm{~min}$ at $95^{\circ} \mathrm{C}$. Antibodies against $B$. subtilis levanase $(20 \mu \mathrm{l})$ and $10 \%(\mathrm{w} / \mathrm{v})$ Protein-A-Sepharose $(80 \mu \mathrm{l})($ Sigma) in TNET were then added to $0.3 \mathrm{ml}$ dialysed supernatants and to the disrupted cells. After overnight incubation at $4{ }^{\circ} \mathrm{C}$, the immunoprecipitates were recovered by centrifugation. The pellets were washed three times with $1 \mathrm{ml}$ TNET and finally resuspended in electrophoresis sample buffer. The samples were boiled for $3 \mathrm{~min}$ and analysed by SDS-PAGE.

Purification of levanase. Exocellular levanase was purified from the supernatant of strain GM96201 harvested at the end of the exponential phase of growth. Supernatant was first concentrated 20 -fold on a bioconcentrator miniplate (Millipore), then the enzyme was obtained in a pure state after the successive chromatographic steps, as follows.

Step 1: hydroxylapatite (HA) chromatography. The supernatant, concentrated from $3 \mathrm{l}$ culture, was loaded on a HA column $(15 \times 1 \mathrm{~cm})$ pre-equilibrated with $0.1 \mathrm{M}$ sodium phosphate, $\mathrm{pH} 6.5$.

The column was washed with the same buffer, and proteins were eluted with a linear gradient of sodium phosphate from 0.1 to $0.8 \mathrm{M}$. Levanase activity was eluted by $0.5 \mathrm{M}$ phosphate. Fractions containing activity were pooled, dialysed against $0.1 \mathrm{M}$ sodium phosphate, $\mathrm{pH} 6.5$, and re-concentrated up to $2 \mathrm{ml}$ with vivaspin (Vivascience).

Step 2: gel-filtration chromatography. We ran gel-filtration chromatography using a $70 \times 2.5 \mathrm{~cm}$ Biogel P150 column (200-400 mesh; Bio-Rad) with continuous elution at a constant rate of $45 \mathrm{ml} \mathrm{h}^{-1}$ at $5^{\circ} \mathrm{C}$ with $0.1 \mathrm{M}$ sodium phosphate, $\mathrm{pH}$ 6. Fractions containing levanase activity were pooled and dialysed against $0.01 \mathrm{M}$ sodium phosphate, $\mathrm{pH} 7$.

Step 3: DEAE-Sepharose chromatography. The dialysed protein solution was loaded on a DEAE-Sepharose anion-exchange column $(20 \times 1 \mathrm{~cm})$ pre-equilibrated with $0.01 \mathrm{M}$ sodium phosphate, $\mathrm{pH} 7$. The column was washed with the same buffer and proteins were eluted with a linear gradient of $0-0.6 \mathrm{M} \mathrm{NaCl}$. Levanase activity was eluted by $0.4 \mathrm{M} \mathrm{NaCl}$.

Purified levanase migrated as a single protein band on $10 \%$ (w/v) SDS-PAGE and had an apparent molecular mass of $73000 \mathrm{Da}$

Antibodies against levanase. Antibodies raised in rabbits were prepared against pure levanase.

\section{RESULTS}

\section{Construction of strain GM96201 overproducing levanase during the exponential phase of growth}

The BamHI-StuI fragment of pGMC11 carrying the fusion of $\mathrm{P}_{s a c B}$ to the $s a c C$ structural gene was ligated between the BamHI/EcoRV sites in pGMK50 (PetitGlatron \& Chambert, 1992) to give pGMK64, an integrative plasmid in which the sacC gene is under the

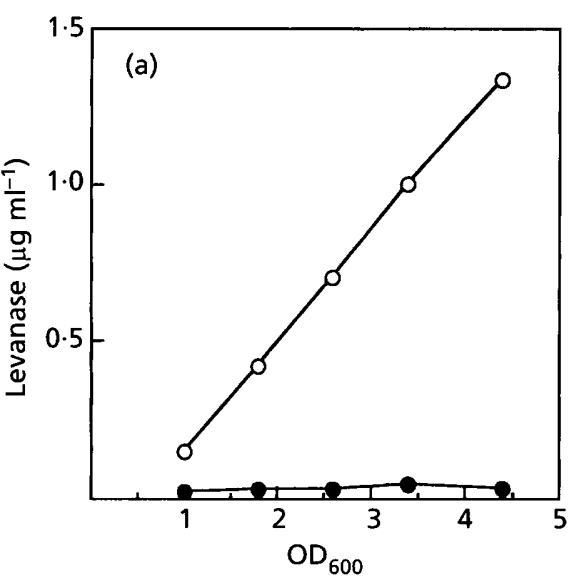

(b)

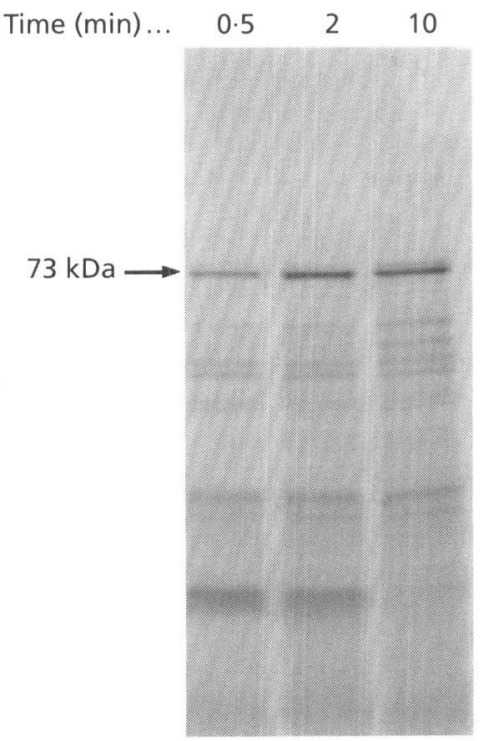

Fig. 1. Production of exocellular levanase in strain GM96201 during the exponential phase of growth. Bacteria from strain GM96201 induced (O) or not (0) with $60 \mathrm{mM}$ sucrose were grown in minimal medium supplemented with $1 \%(w / v)$ glucose at $37^{\circ} \mathrm{C}$. Samples were withdrawn at intervals, their $\mathrm{OD}_{600}$ was measured and then they were centrifuged. (a) Supernatants were dialysed against $0.1 \mathrm{M}$ sodium phosphate, $\mathrm{pH} 6$, and assayed for activity. (b) At an $O_{600}$ of 2, a $1 \mathrm{ml}$ aliquot of the induced culture suspension was pulse-labelled for $45 \mathrm{~s}$ with $0.9 \mathrm{MBq}{ }^{35} \mathrm{~S}$ ]methionine $\left(800 \mathrm{Ci} \mathrm{mmol}^{-1}\right)$ and chased with a large excess of non-radioactive methionine $(4 \mathrm{mM}$ final concentration). Samples were removed at intervals and centrifuged. Supernatants were analysed by SDS-PAGE. 
(a)
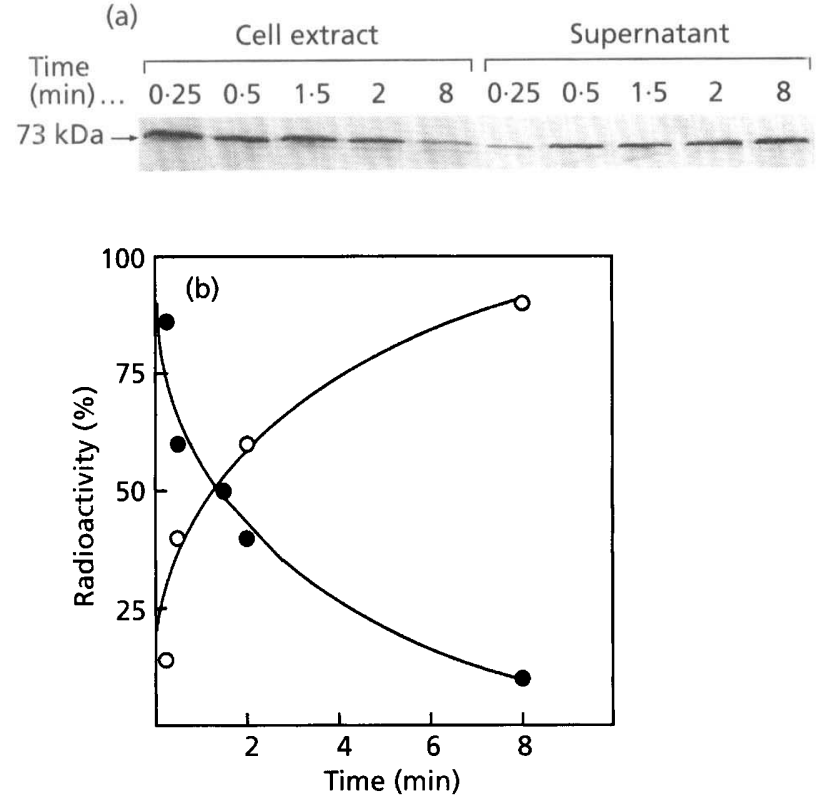

Fig. 2. Pulse labelling experiment. Bacteria of strain GM9620 were induced with $60 \mathrm{mM}$ sucrose in the exponential phase of growth. At an $\mathrm{OD}_{600}$ of 2 , a $1 \mathrm{ml}$ aliquot of the culture suspension was pulse-labelled for $45 \mathrm{~s}$ with $0.9 \mathrm{MBq}$ ${ }^{35} \mathrm{~S}$ ]methionine $\left(800 \mathrm{Ci} \mathrm{mmol}^{-1}\right)$ and chased with a large excess of non-radioactive methionine ( $4 \mathrm{mM}$ final concentration). Samples were removed at intervals, treated and analysed as described in Methods. (a) SDS-PAGE of labelled cell-associated and exocellular levanase. (b) At each time point, exocellular $(O)$ or cell-associated (O) levanase is shown as a fraction of total levanase (exocellular + cell-associated). Quantification was performed with a Phosphor-Imager.

control of the $s a c B$ leader region. pGMK64 was integrated by a Campbell-like mechanism into the chromosome of GM96100 (Leloup et al., 1997). The transformants were selected from LB plates containing the appropriate antibiotic. We confirmed the presence of the $s a c R-s a c C$ fusion in the transformants by PCR using appropriate oligonucleotides. One of the transformants containing the $\mathrm{P}_{s a c B}-s a c C$ fusion and exhibiting sucroseinducible expression of levanase was chosen for further analysis and named GM96201.

When strain GM96201 was grown in the absence of sucrose, no levanase activity (Fig. 1a) or labelled levanase (pulse experiment, not shown) was detected in the supernatant. In the presence of sucrose, production of exolevanase occurred at a constant differential rate of synthesis, $5 \mu \mathrm{g} \mathrm{mg}^{-1}$, during the exponential phase of growth. Pulse experiments (Fig. 1b) showed that levanase is one of the major proteins released into the growth medium. The molecular mass of secreted levanase is $73 \mathrm{kDa}$ as expected from the nucleotide sequence of the structural gene sacC (Schörgendorfer $e t$ al., 1987). We observed that the production of exocellular levanase is around ten times lower than that of levansucrase in the parent strain QB112 (Chambert \& Petit-Glatron, 1984). This point will be discussed later. (a)
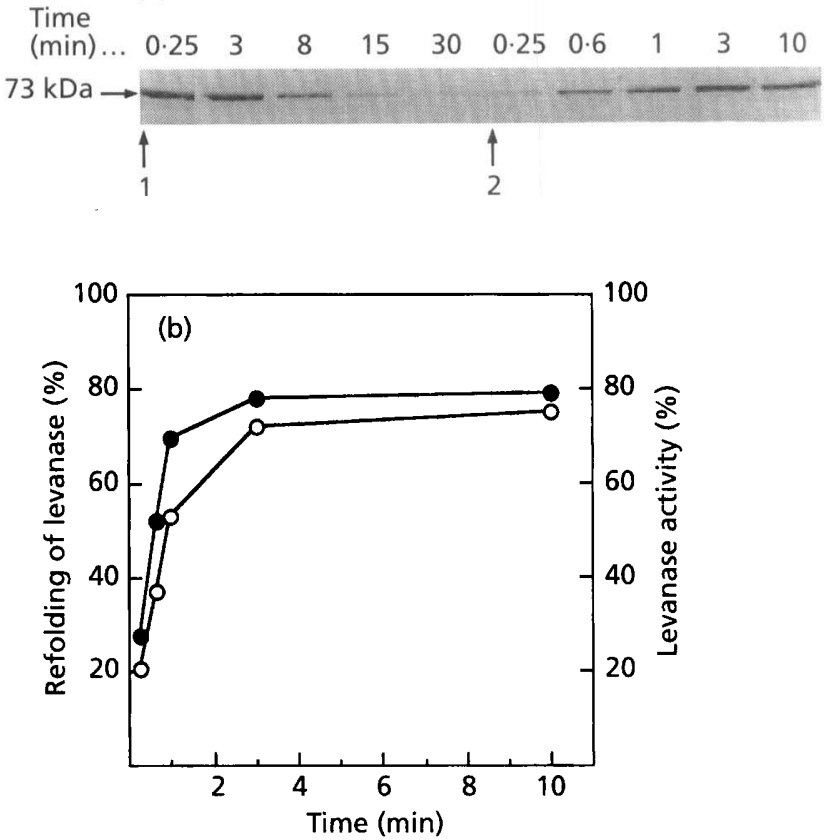

Fig. 3. Kinetics of the unfolding-refolding transition of $B$. subtilis levanase measured by resistance to proteolysis at $37^{\circ} \mathrm{C}$, $0.1 \mathrm{M}$ sodium phosphate, at $\mathrm{pH} 7$. Unfolding was promoted (arrow 1) by mixing $20 \mu$ l stock solution of purified levanase $\left(1.5 \mathrm{mg} \mathrm{ml}^{-1}\right)$ with $150 \mu \mathrm{l} 10 \mathrm{M}$ urea, $\mathrm{pH} 7$. Samples $(8 \mu \mathrm{l})$ were withdrawn at the times indicated and quickly mixed with $92 \mu \mathrm{l}$ $0.1 \mathrm{M}$ sodium phosphate, $\mathrm{pH} 7$, containing $10 \mu \mathrm{g}$ subtilisin $\mathrm{ml}^{-1}$. Refolding was initiated (arrow 2) after $30 \mathrm{~min}$ unfolding by mixing $40 \mu \mathrm{l}$ unfolding mixture with $460 \mu \mathrm{l} 0.1 \mathrm{M}$ sodium phosphate, $\mathrm{pH} 7$, containing $0.5 \mathrm{mM}$ calcium. Samples $(100 \mu \mathrm{l})$ were withdrawn at the times indicated and quickly mixed with $2 \mu \mathrm{l}$ of a $0.5 \mathrm{mg}$ subtilisin $\mathrm{ml}^{-1}$ solution, and incubated for $5 \mathrm{~min}$. PMSF was then added to the samples. Aliquots $(80 \mu \mathrm{l})$ of all the samples were subjected to SDS-PAGE. Aliquots $(5 \mu \mathrm{l})$ were analysed for levanase activity. (a) SDS-PAGE analysis of the samples. (b) Quantification of the percentage of the folded protein was obtained from densitometric tracings of the Coomassie-blue-stained gels using the NIH Image program (O) and from measurements of the residual enzyme activity (O).

\section{Sequential stages of the levanase secretion process}

We characterized the discrete stages of the levanase secretion pathway from pulse-chase experiments (Fig. 2 ). We did not detect any unprocessed precursor of levanase whose expected molecular mass is $76 \mathrm{kDa}$ (deduced from the nucleotide sequence). However, a cell-associated form with the same molecular mass as the exocellular protein $(73 \mathrm{kDa})$ disappeared slowly from the cells and was concomitantly released into the culture supernatant. The $t_{1 / 2}$ of this event was evaluated at $80 \mathrm{~s} \pm 10 \mathrm{~s}$ and the yield of the release was almost $100 \%$. Thus, this processed cell-associated levanase displays the features of a transient secretion intermediate of the protein. This precursor was tightly bound to the cells since it was not released after washing the cells at a high ionic strength (see Methods). We have previously characterized a very similar intermediate in the secretion process of levansucrase (Petit-Glatron et al., 1987) and 
(a)
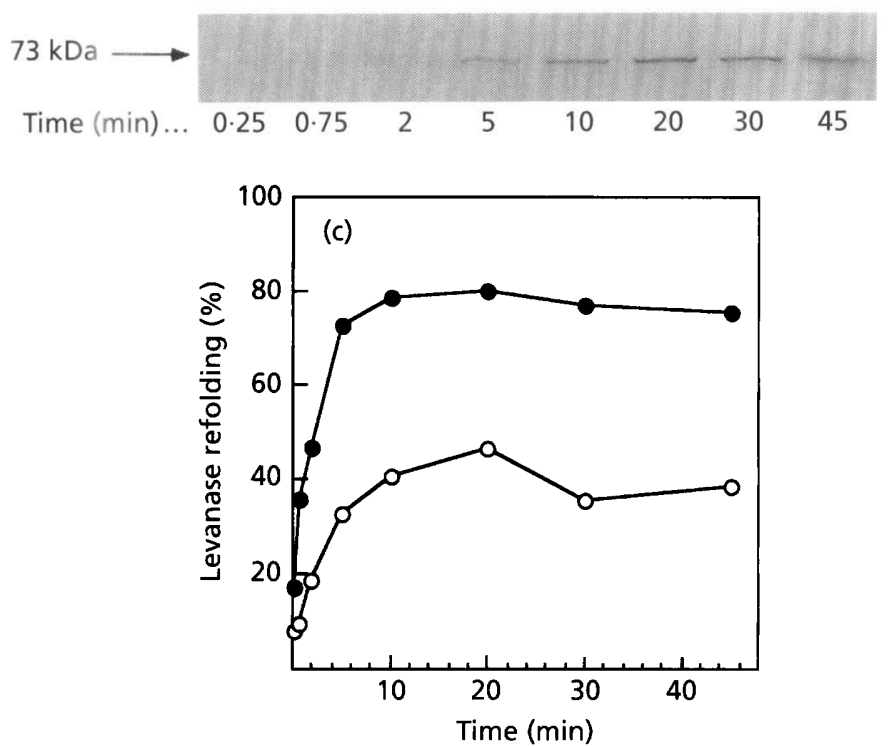

(b)
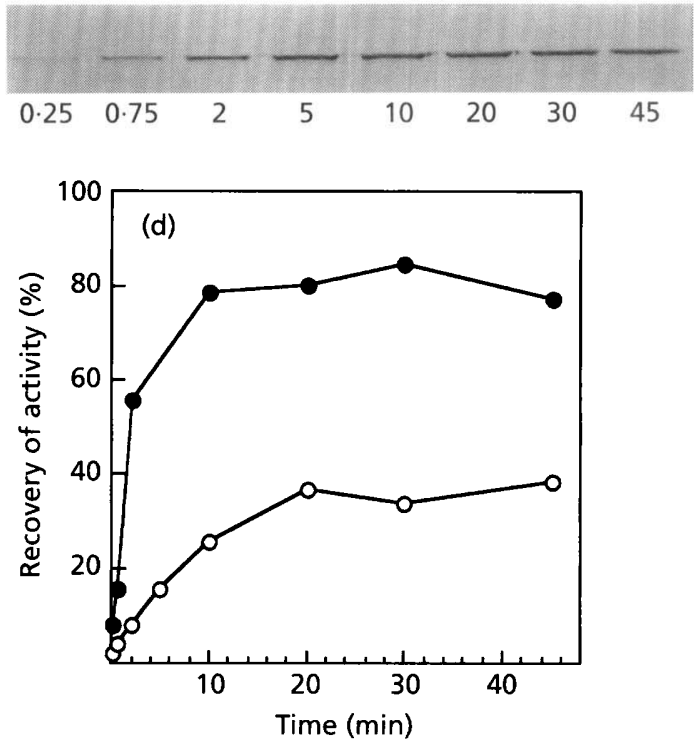

Fig. 4. Unfolding-refolding transition of levanase mediated by $\mathrm{Ca}^{2+}$ at $37^{\circ} \mathrm{C}, \mathrm{pH}$. Stock solution (15 $\left.\mu \mathrm{l}\right)$ of purified protein $\left(1.5 \mathrm{mg} \mathrm{ml}^{-1}\right)$ was preincubated for $30 \mathrm{~min}$ in $105 \mu 110 \mathrm{M}$ urea in $0.1 \mathrm{M}$ sodium acetate at pH 7. Refolding was initiated by mixing $60 \mu \mathrm{l}$ of the unfolding mixture with $700 \mu \mathrm{l} 0.1 \mathrm{M}$ sodium acetate, $\mathrm{pH} 7$, containing or not $20 \mathrm{mM}$ calcium chloride. Samples $(90 \mu \mathrm{l})$ were withdrawn at the time indicated and quickly mixed with $2 \mu \mathrm{l} 1 \mathrm{mg}^{\text {subtilisin } \mathrm{ml}^{-1}}$ solution. Samples were submitted to SDS-PAGE analysis, and were assayed for levanase activity. (a, b) SDS-PAGE analysis of the samples of the refolding experiment (a) in the absence of calcium and (b) in the presence of calcium. (c) Curves obtained from scanning the coloured bands of the SDS gels. (d) Residual enzyme activities were measured in the presence of the same concentration of $\mathrm{Ca}^{2+}(10 \mathrm{mM}$ final concentration). $O$, Refolding in the absence of calcium; refolding in the presence of calcium.

$\alpha$-amylase (Leloup et al., 1997) when these proteins were overproduced. We pointed out that the time constant of the processed precursor release of these two proteins was of the same order of magnitude as the time constants of in titro refolding of the proteins occurring under the same conditions of $\mathrm{pH}$, temperature and ionic strength. We tested whether a similar correlation could be observed with levanase.

\section{Kinetics of unfolding-refolding of levanase in vitro: calcium is a modulator of the folding reaction}

The unfolding-folding transition was measured by monitoring the appearance and disappearance of the subtilisin sensitivity of the protein (Fig. 3). In the presence of $8.75 \mathrm{M}$ urea, at $\mathrm{pH} 7$ and $37^{\circ} \mathrm{C}$, unfolding occurred with a $t_{1 / 2}$ of $7 \pm 1 \mathrm{~min}$. After dilution of the denaturing agent in $0 \cdot 1 \mathrm{M}$ sodium phosphate, $\mathrm{pH} 7$, at $37^{\circ} \mathrm{C}$, the unfolding-folding transition occurred with a high yield $(Y=80 \%)$ and the $t_{1 / 2}$ of the reaction was $46 \pm 5 \mathrm{~s}$. The rate of levanase refolding is therefore approximately the same as that of in vivo release of the protein under the same conditions of $\mathrm{pH}$, temperature and ionic strength. Similar observations have been made for levansucrase (Chambert et al., 1995) and $\alpha$-amylase (Leloup et al., 1997). We proposed that the release and folding processes are coupled on the external side of the cytoplasmic membrane. Moreover, we identified the calcium ion as being a folding modulator that can assist such a coupling (Petit-Glatron et al., 1993). In the case of levanase, we observed that the presence of calcium increases the rate and yield of refolding (Fig. 4). We examined the ability of levanase to bind calcium in comparison to other secreted proteins by the method of Maruyama et al. (1984) using a dot blot assay with pure proteins (Fig. 5). The radioactive spots were quantified by phosphor-imaging. The ability of levanase to bind calcium was approximately the same as that of levansucrase. Therefore, we can reasonably conclude that levanase, $\alpha$-amylase and levansucrase have some common folding properties: calcium increased the rate of refolding of each protein; however, the affinities of the native proteins to calcium are very low. The folding catalyst effect of calcium could play an important role in the final stage of their secretion processes.

\section{DISCUSSION}

The expression of $s a c C$ under the control of the leader region of levansucrase led to an overproduction of exocellular levanase during the exponential phase of growth of B. subtilis. Pulse-chase experiments showed some differences in the timing of the cellular sequential events leading to secretion compared with those of levansucrase. In contrast to levansucrase, we observed no unprocessed intermediates in the sequential process of levanase secretion, suggesting that the precursor processing is very rapid. The same result was obtained 
(a)

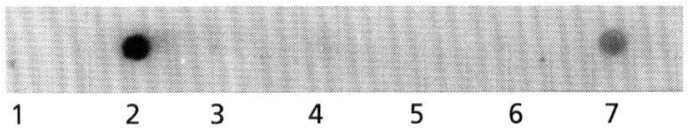

(b)

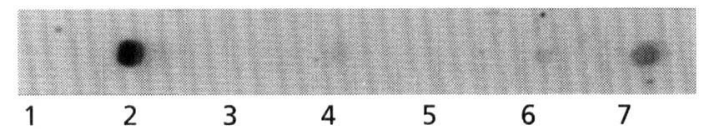

(c)

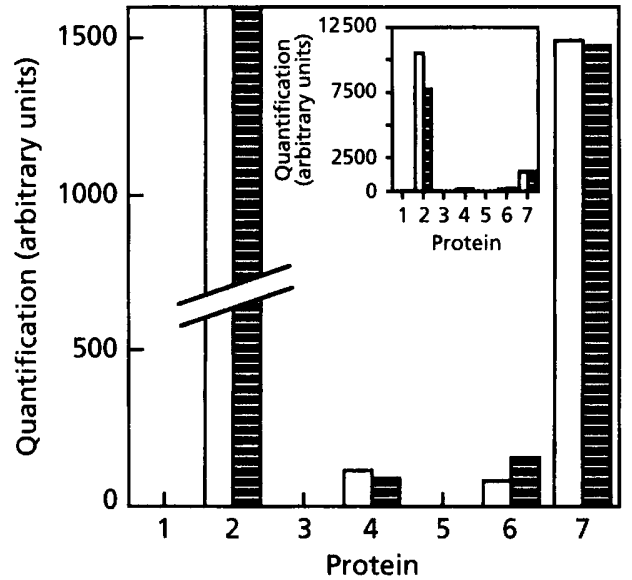

Fig. 5. Calcium-binding properties of several $B$. subtilis exocellular enzymes. Pure proteins $(2 \mu \mathrm{g})$ were blotted onto nitrocellulose. Membrane pieces (a) and (b) were equilibrated for $15 \mathrm{~min}$ at room temperature in $0.1 \mathrm{M}$ potassium acetate or $0.1 \mathrm{M}$ potassium phosphate, $\mathrm{pH} 7$, respectively. Then each piece of membrane was incubated for $1 \mathrm{~h}$ in $1 \mathrm{ml}$ of the same buffer containing $10 \mu \mathrm{Ci}(370 \mathrm{kBq}){ }^{45} \mathrm{CaCl}_{2}$. After 20 min washing in a large volume of buffer, the membranes were dried, exposed to a Kodak X-Omat film and quantified by phosphor-imaging (c). Open bars, calcium binding shown in (a); striped bars, that shown in (b). 1 and 3, ovalbumin and bovalbumin used as controls of non calcium-binding proteins; $2, \alpha$-amylase of Bacillus licheniformis; 4 , levansucrase; $5, \alpha$-amylase of $B$. subtilis; 6 , levanase; $7, \alpha$-amylase of Bacillus amyloliquefaciens.

when $\alpha$-amylase was expressed in the same genetic and physiological context (Leloup et al., 1997). Since these three proteins are all native exocellular proteins of $B$. subtilis, these intriguing results led us to assume that the rate of the leader peptide cleavage depends on features that are intrinsic to this peptide. Alternatively, the efficiency of the initial step of secretion, i.e. the entry into the export pathway via its association with SecA (den Blaauwen \& Driessen, 1996), is different and specific to each leader peptide. The signal sequence of levansucrase is very different to that of levanase and $\alpha$ amylase. The h-domain of these two latter proteins is 1.5 times longer than that of levansucrase and their overall hydrophobicity is much greater. Furthermore, the net charge of the first amino acids immediately downstream from the signal sequence is negative for $\alpha$-amylase and levanase and positive for levansucrase. Further experiments dealing with exchange of leader peptides between these proteins should provide new insights into these issues.
The most exciting result obtained in this work concerns the kinetic characterization of the ultimate stage of the secretion process, i.e. the release of the processed protein. Levanase is the third model protein for which we have observed that the half-life of such an event is similar to the half-life of in vitro refolding of the protein occurring under the same conditions of $\mathrm{pH}$, temperature and ionic strength. Furthermore, these two events occur within the same time range $\left(t_{1 / 2}=1-2 \mathrm{~min}\right)$ for the three proteins despite their large molecular mass difference. These results suggest that the rate of the release stage, which includes the crossing of the cell wall, is not dependent on protein size as it was previously postulated (Demchick \& Koch, 1996), but rather dependent on their folding rate. The final point of interest concerns the difference in the levels of synthesis of levanase and levansucrase even though the two structural genes were under the same transcriptional control. Levanase synthesis is ten times lower than that of levansucrase. Similar results have been reported for $\alpha$-amylase, whose level of synthesis is about five times lower (Leloup et al., 1997), and also for other heterologous model proteins expressed under the regulatable control of the levansucrase leader region (Simonen \& Palva, 1993).

For the expression of heterologous proteins this difference was generally explained by post-transcriptional events such as the inability of the secretory apparatus to recognize foreign proteins, the protease sensitivity of these proteins or competition for the secretion apparatus. We have demonstrated unambiguously that, for the expression of homologous $\alpha$-amylase and levanase, none of these explanations applies because the proteins adopt in vitro a proteolytically insensitive structure at approximately the same rate as levansucrase and their levels of production remain the same in strains deleted or not for the levansucrase structural gene. Presumably the difference in the production level is mostly due to differences in transcription or translational efficiency. Preliminary experiments have indicated that the level of $\alpha$-amylase and levanase mRNAs in fully induced strains correlates with respective protein production. This disparity may be due to differences in mRNA stability or to other factors as yet unknown. A difference in codon usage could also affect the rate of mRNA translation depending on the phase of production of the different genes (Steinmetz et al., 1985; Shields \& Sharp, 1987).

\section{ACKNOWLEDGEMENTS}

We are grateful to A. Kropfinger for revision of the English text. This work was supported in part by the European Commission (Biotech programme BIO4-CT96-0097) and was carried out within the framework of the European Bacillus Secretion Group.

\section{REFERENCES}

den Blaauwen, T. \& Driessen, A. J. (1996). Sec-dependent preprotein translocation in bacteria. Arch Microbiol 165, 1-8. 
Chambert, R. \& Petit-Glatron, M. F. (1984). Hyperproduction of exocellular levansucrase by Bacillus subtilis: examination of the phenotype of a sacU ${ }^{\text {h }}$ strain. J Gen Microbiol 130, 3143-3152.

Chambert, R. \& Petit-Glatron, M. F. (1993). Immobilisation of levansucrase on calcium phosphate gel strongly increases its polymerase. Carbohydr Res 244, 129-136.

Chambert, R., Haddaoui, E. A. \& Petit-Glatron, M. F. (1995). Bacillus subtilis levansucrase: the efficiency of the second stage of secretion is modulated by external effectors assisting folding. Microbiology 141, 997-1005.

Demchick, P. \& Koch, A. L. (1996). The permeability of the wall fabric of Escherichia coli and Bacillus subtilis. J Bacteriol 178, 768-773.

Ferrari, E., Nguyen, A., Lang, D. \& Hoch, J. (1983). Construction and properties of an integrable plasmid for Bacillus subtilis. $J$ Bacteriol 154, 1513-1515.

Fuchs, A. (1959). On the synthesis and breakdown of levan by bacteria. Thèse de doctorat, Leiden University.

Kunst, F., Steinmetz, M., Lepesant, J. A. \& Dedonder, R. (1977). Presence of a third sucrose hydrolyzing enzyme in Bacillus subtilis: constitutive levanase synthesis by mutants of Bacillus subtilis Marburg 168. Biochimie 59, 289-292.

Leloup, L., Haddaoui, E., Chambert, R. \& Petit-Glatron, M. F. (1997). Characterization of the rate limiting step of the secretion of Bacillus subtilis $\alpha$-amylase overproduced during the exponential phase of growth. Microbiology 143, 3295-3303.

Lepesant, J. A., Kunst, F., Pascal, M., Lepesant-Kejzlarova, J., Steinmetz, M. \& Dedonder, R. (1976). Specific and pleiotropic regulatory mechanism in the sucrose system of Bacillus subtilis. In Microbiology-1976, pp. 58-69. Edited by D. Schlessinger. Washington, DC: American Society for Microbiology.

Maruyama, K., Mikawa, T. \& Ebashi, S. (1984). Detection of calcium binding proteins by ${ }^{45} \mathrm{Ca}$ autoradiography on nitrocellulose membrane after sodium dodecyl sulfate gel electrophoresis. J Biochem 95, 511-519.

Petit-Glatron, M. F. \& Chambert, R. (1992). Peptide carrier potentiality of Bacillus subtilis levansucrase. J Gen Microbiol 138, 1089-1095.

Petit-Glatron, M. F., Benyahia, F. \& Chambert, R. (1987). Secretion of Bacillus subtilis levansucrase: a possible two step mechanism. Eur J Biochem 163, 379-387.

Petit-Glatron, M. F., Grajcar, L., Munz, A. \& Chambert, R. (1993). The contribution of the cell wall to a transmembrane calcium gradient could play a key role in Bacillus subtilis protein secretion. Mol Microbiol 9, 1097-1106.

Schörgendorfer, K., Schwab, H. \& Lafferty, R. M. (1987). Nucleotide sequence of a cloned $2.5 \mathrm{~kb}$ PstI-EcoRI Bacillus subtilis DNA fragment coding for levanase. Nucleic Acids Res 15, 9606.

Scotti, P. A., Præstegaard, M., Chambert, R. \& Petit-Glatron, M. F. (1996). The targeting of Bacillus subtilis levansucrase in yeast is correlated to both the hydrophobicity of the signal peptide and the net charge of the $\mathrm{N}$-terminus mature part. Yeast 12, 953-963.

Shields, D. C. \& Sharp, P. M. (1987). Synonymous codon usage in Bacillus subtilis reflects both translational selection and mutational bias. Nucleic Acids Res 15, 8023-8040.

Simonen, M. \& Palva, I. (1993). Protein secretion in Bacillus species. Microbiol Rev 57, 109-137.

Steinmetz, M., Le Coq, D., Aymerich, S., Gonzy-Tréboul, G. \& Gay, P. (1985). The DNA sequence of the gene for the secreted Bacillus subtilis enzyme levansucrase and its genetic control sites. Mol Gen Genet 200, 220-228.

Received 18 August 1998; revised 5 November 1998; accepted 10 November 1998. 